Braga, O. ; Smythe, G.A. ; Schäfer, A.I. ; Feitz, A.J. (2005) Fate of steroid estrogens in Australian inland and coastal wastewater treatment plants Environmental Science \& Technology, 39, 3351-3358. PLUS CORRECTION: (18): 7344-7344

\section{Fate of steroid estrogens in Australian inland and coastal wastewater treatment plants}

Olga Braga ${ }^{1}$, George A. Smythe ${ }^{1}$, Andrea I. Schäfer ${ }^{2}$ and Andrew J. Feitz ${ }^{3 *}$

${ }^{1}$ Bioanalytical Mass Spectrometry Facility, Faculty of Medicine, University of New South Wales, Sydney NSW 2052, Australia

${ }^{2}$ Civil, Mining and Environmental Engineering, University of Wollongong, Wollongong NSW 2522, Australia

${ }^{3}$ Centre for Water and Waste Technology, School of Civil and Environmental Engineering, University of New South Wales, Sydney NSW 2052, Australia

Environmental Science and Technology (Revised version January 2005): note also CORRECTION published in EST 39(18): 7344

* Corresponding author: Phone +61 29385 5082, fax: +61 229313 8624, email andrew.feitz@unsw.edu.au

\section{Abstract}

A comparison of estrone (E1), 17 $\beta$-estradiol (E2) and 17 $\alpha$-ethinylestradiol (EE2) removal at a coastal enhanced primary and inland advanced sewage treatment plant (STP) is reported. The average enher concen a ( removal was obsered during later microfitration with the estrogen concentration below detection $\left(<0.1\right.$ ng. $\mathrm{L}^{-1}$ after reverse osmosis. Some $6 \%$ of the influent $\mathrm{El}+\mathrm{E} 2 \mathrm{w}^{-1}$ removed in the waste activate sludge. The detection of EE2 in the waste activated sludge ( $0.42 \mathrm{ng} \cdot \mathrm{g}^{-1}$ solids dry weight), undetectable in the raw sewage, suggests that EE2 is resistant to biological treatment in the sequential batch reacto and is primarily removed due to sorption. Little estrogen removal was observed at the enhance primary with only $7 \%$ of E1 and $0 \%$ of E2 removed. Low removal is expected based on the degree of estrogens partitioning in the organic fraction given the relatively low solids concentration, bu surprisingly, some $43 \%$ of E2, 24\% of E1 and $100 \%$ of EE2 remains associated with the solids fraction in the treated effluent. Further research is necessary to determine whether the low level of estrogen removal for the coastal treatment plant will adversely affect the receiving marine environment.

\section{Introduction}

There are increasing concerns that the release of steroid estrogens post wastewater treatment is leading to abnormal reproductive systems in freshwater and marine dwelling animals (1-3). Human excretion is considered to be the primary source of steroid estrogens from the urban environment and are is released by individuals into sewerage system in both conjugated and unconjugated forms at $\mu \mathrm{g}$ levels per day (4-6). Johnson and Williams (6) recently developed a model to estimate the quantities of estrogens by the human population, taking in consideration conjugation and metabolism of natural and synthetic hormones in the body and the different quantities released by different population groups. The average human excretion of estrogens per head is reported to be $10.5 \mu \mathrm{g.d} \mathrm{d}^{-1}$ for estrone (E1), 6.6 $\mu \mathrm{g} . \mathrm{d}^{-1}$ for $17 \beta$-estradiol (E2), with an additional $3.3 \mu \mathrm{g} \cdot \mathrm{d}^{-1}$ transformation of the $\mathrm{E} 1$ to $\mathrm{E} 2$ in the sewer (6). The population normalized concentration of the synthetic steroid $17 \alpha$-ethinylestradiol, an active (6). The population normalized concentration of the synt
agent in the contraceptive pill, is $1 \mu \mathrm{g} \cdot \mathrm{d}^{-1}$ per head (6).

While there are increasing data on the presence of estrogens in rivers (7-9), coastal samples $(10,11)$ and in the sediments of river beds (12-15), lakes $(16)$ and estuaries $(17,18)$, relatively little is known about the movement or degradation characteristics of individual human estrogens within wastewater treatment systems. Sorption to sludge is likely to play an important role in the initial removal of these compounds during wastewater treatment $(4)$ as the octanol-water partition coefficients $\left(\mathrm{K}_{\mathrm{ow}}\right)$ for E2 $\left(\log \mathrm{K}_{\text {ow }}=3.9\right), \mathrm{E} 1\left(\log \mathrm{K}_{\text {ow }}=3.4\right)$ and $\mathrm{EE} 2\left(\log \mathrm{K}_{\text {ow }}=4.1\right)(5)$ are moderately high, although lower $\mathrm{K}_{\text {ow }}$ have been obtained by Holthaus et al (19) for E2 and E1. The concentration of estrogens in the raw wastewater (20-22) and in treated effluent (23-20) is well chaction cycle during watment $(27,28)$. The recent study by Holbrook et al. (27), using an estradiol-equivalent screening assay, suggests that the treated effluent contains the greatest estrogenic activity with the sludge only accounting for approximately $10 \%$ of the influent estrogenic activity. This paper attempts to provide greater detail on the movement of E1, E2 and EE2 through two different Australian sewage treatmen plants (STP) and focuses on the fate of these compounds in the solids cycle.

\section{Materials and Methods}

Sampling Sites

A small inland advanced sewage treatment plant (STP) and large coastal enhanced primary STP were selected for the study in order to assess steroid estrogen removal rates for different unit operations. The advanced STP is located in western Sydney and services only domestic sewage from a nearby suburb (population app loxim W treatment (2 sequential batch reactors (SBRs)) wh an average flow of 1.9 ML.d. The secondary effluent is taken to the tetiany reation (CMF) (exclusion size $0.2 \mu \mathrm{m}$ ), reverse osmosis (RO) and chlorination/de-chlorination. It provides $852 \mathrm{ML}$ of recycled water each year from sewage and stormwater. The activated sludge treatment consists of two basins, each $987 \mathrm{~kL}$ in volume, with anoxic and aerobic zones. The volume of the aerobic zone, where sludge is monitored and wasted from, is $775 \mathrm{~kL}$ and the sludge in the basin is kept at $30 \%$ of the total volume. Approximately $37 \mathrm{~kL}$ of the activated sludge is wasted each day and sent for dewatering. The solids retention time (SRT) is approximately 16 days and the hydraulic retention time in the SBR is 4 hours ( 2 hours each in the anoxic zone and aerobic zones). The coastal enhanced primary STP is located in eastern Sydney and services domestic sewage (75\%) and industrial wastewater (25\%) with an equivalent population of $1,700,000$. It provides enhanced primary treatment (i.e. with $\mathrm{FeCl}_{3}$ perage flow of $480 \mathrm{ML} \cdot \mathrm{d}^{-1}$ and hydraulic retention time of $45 \mathrm{~min}$ by deep ocean discharge $3.6 \mathrm{~km}$ offshore at an average of $80 \mathrm{~m}$ depth. 
Braga, O. ; Smythe, G.A. ; Schäfer, A.I. ; Feitz, A.J. (2005) Fate of steroid estrogens in Australian inland and coastal wastewater treatment plants,

\section{Standard and SPE Preparation}

Estrone (E1), estradiol (E2), ethinylestradiol (EE2), and deuterated E1, 4,16,16- $d 4$ (d4- E1) were obtained from Sigma Aldrich (Sydney, Australia). The d4- E1 was used as the internal standard. Stock solutions of individual non-deuterated standards and deuterated internal standard were prepared by dissolving known amounts of in methanol to obtain a concentration of $0.10 \mathrm{mg} \cdot \mathrm{mL}^{-1}$. Working standard solutions were obtained by further diluting stock solutions with water to obtain final concentrations of $0.5 \mathrm{pg} \cdot \mu \mathrm{L}^{-1}$ to $500 \mathrm{pg} \cdot \mu \mathrm{L}^{-1}$. The stock solution of internal standard was further diluted with water to obtain a final concentration of $100 \mathrm{pg} . \mu \mathrm{L}^{-1}$. HPLC grade methanol and acetonitrile were obtained from Ajax Finechem (Sydney, Australia). Other solvents were of analytical grade and they were used as supplied. Milli-Q water was used for all experimental procedures. Analytes were extracted from supplied. aqueous saco, (he Manifold (Supelco, Sydney, Austratic $1 \times 10 \mathrm{~mL}$ Milli-Q water

\section{Sample Collection}

Duplicate grab samples were collected in 1L Pyrex glass bottles from each sampling point within the two STPs. In the advanced STP, samples were collected from the raw sewage, outlet from sequential batch reactor (SBR), inlet/outlet from cross flow microfiltration (CMF), outlet from reverse osmosis (RO), after chlorination, from the wasted mixed liquor suspended solids (MLSS) and from the dewatered sludge. For the enhanced primary STP, samples were collected from the raw sewage an treated effluent. All samples were passed though SPE, dried and stored in a 10-mL tube on the collection day. The stored samples were analysed together once sampling was finished (normally week after collection). All samples at each of the plants were taken at the same time of day, $8-8.30$ am, during weekdays, periodically over a period of 4 months for the advanced STP and between $10-$ $10.30 \mathrm{am}$, during weekdays, periodically over a period of 1 year for the enhanced primary STP.

\section{Sample Preparation and Solid Phase Extraction}

Water: Analytes were extracted from $0.5 \mathrm{~L}$ (raw sewage) to $1 \mathrm{~L}$ for all other samples. Before samples were processed, internal standard (see above) was added to each sample, followed by the removal of suspended particle by a prefiltration step with an AP-15 filter (Millipore, Sydney, Australia). This step was performed to avoid SPE cartridge plugging. Sample loading was achieved by passing standards and environmental water samples through the LC-18 SPE cartridge. After sample loading, cartridges were dried in a vacuum desiccator for 30 to $40 \mathrm{~min}$. Elution of the analytes was achieved by passing $2 \times 5 \mathrm{~mL}$ methanol that was collected in a $10 \mathrm{~mL}$ culture tube with screw cap. The collected solution was dried down under vacuum and reconstituted to $1 \mathrm{~mL}$ with acetone before derivatisation and analysis.

Sludge: Before samples were processed, internal standard (see above) was added to a $50 \mathrm{~mL}$ sludge sample, followed by autoclaving and freeze-drying. The dried pellets were weighed and then dissolved in a mixture of $100 \mathrm{~mL}$ acetone/hexane (50:50). The solvent-sample slurry was then sonicated for 30 min followed by heating at $80^{\circ} \mathrm{C}$ for an hour in a water bath. The solvent-sample mixture was then filtered through Whatman No. 1 glass fibre filter paper (Whatman, Sydney, Australia), the pellet rinsed with a mixture of acetone/hexane (50:50), followed by solvent evaporation in a rotatory evaporator. with a mixture of acetone/hexane (50:50), followed by solvent evaporation in a rotatory evaporator.
The residues were dissolved in water and an extraction was carried out with LC-18 SPE (see above) The residues were dissolved in water and
before sample derivatization and analysis.

\section{Sample Derivatization for GC-MS Analysis}

The derivatization was carried out using a modified version of the method used by Nakamura et al (30) for the pentafluorobenzyl-trimethylsilyl derivative. To the acetone extract, $100 \mu \mathrm{L}$ of $10 \%$ aqueous potassium carbonate and $10 \mu \mathrm{L}$ of pentafluorobenzylbromide reagent were added, and were kept at $70^{\circ} \mathrm{C}$ for 1 hour. After cooling, the solvent was reduced to $100 \mathrm{uL}$ under vacuum. $1 \mathrm{~mL}$ of toluene was added, and the organic phase was washed with $0.5 \mathrm{~mL}$ of Milli-Q water. The water layer was discarded and the toluene layer completely removed under vacuum. $100 \mu \mathrm{L}$ of trimethylsililacetamide was then and the toluene layer completely removed under vacuum. $100 \mu \mathrm{L}$ of trimethylsililacetamide was then
added to the vial and kept at room temperature for $30 \mathrm{~min}$. Toluene was added to $1 \mathrm{~mL}$ before analyses.

\section{Gas Chromatography Mass Spectrometry Conditions}

All GC-MS analyses were carried out using an Agilent 5890 gas chromatograph interfaced to an Agilent 5989B MS Engine (Agilent Technologies, Ryde, Australia). Chromatographic separations were performed with an HP-5MS capillary column ( $30 \mathrm{~m} \times 0.25 \mathrm{~mm}$ i.d. x $0.25 \mu \mathrm{m}$ film thickness). The GC oven temperature was programmed at $150^{\circ} \mathrm{C}$ for $1.5 \mathrm{~min}$ and then $36^{\circ} \mathrm{C}$ per minute to $310^{\circ} \mathrm{C}$, final hol $7.0 \mathrm{~min}$. The GC-MS interface heater, the ion source, quadupole, and injection port temperatures were maintained at $260,240,100$ and $260^{\circ} \mathrm{C}$, respectively. Pulse splitless injection was used with a pulse 
Braga, O. ; Smythe, G.A. ; Schäfer, A.I. ; Feitz, A.J. (2005) Fate of steroid estrogens in Australian inland and coastal wastewater treatment plants

pressure of $241 \mathrm{kPa}(1.1 \mathrm{~min})$ and purge time delay of $8 \mathrm{~min}$. The MS analyses were performed with an electron-capture negative-ion (ECNI) source, using methane as reagent gas (Ultrapure grade, Matheson Gas Products Inc.) and selected ion monitoring mode. The $\left[\mathrm{M}^{-}\right]$ion and $[\mathrm{M}-\mathrm{TMS}]$ ions were monitored for all compounds with a dwell time of $100 \mathrm{~ms}$ per single ion. The injection volume was $1.0 \mu \mathrm{L}$

\section{Recoveries and blanks}

For the determination of recoveries, the raw sewage and secondary and tertiary effluents were spiked with stock solution containing the individual non-deuterated and deuterated steroid estrogens. The resulting concentration were varied and ranged between $1 \mathrm{ng} . \mathrm{L}^{-1}$ to $100 \mathrm{ng} . \mathrm{L}^{-1}$. The blank samples of each matrix were only spiked with the internal standard.

\section{Calibration and Quantification}

The working solutions containing all the estrogens (non-deuterated and deuterated) at accurate defined concentrations were derivatized as described above. Quantification was carried out by calculation of the response factors (RF) based on the area of the non-deuterated and deuterated estrogens standard. These ratios were converted to concentrations using a linear regression equation, which was used to assign the unknown concentrations. Signals for method limit of detection (LOD) and limit of quantification (LOQ) was set at 3- and 6-fold height of noise, respectively

\section{Results and Discussion}

\section{Detection limits and recoveries of the SPE-GC-MS method}

The instrumental limit of detection (LOD) for E2 and EE2 was $0.1 \mathrm{pg} . \mu \mathrm{L}^{-1}$ of injection and for E1 was $0.5 \mathrm{pg} . \mu \mathrm{L}^{-1}$ injection, which was estimated at a signal-to-noise ratio of 3 . The method limit of quantification (LOQ) was determined to be $1 \mathrm{ng} . \mathrm{L}^{-1}$ for raw sewage $\left(5 \mathrm{ng} . \mathrm{L}^{-1}\right.$ for EE2 in raw sewage) quantification (LOQ) was determined to be $1 \mathrm{ng} . \mathrm{L}^{-1}$ for raw sewage ( $5 \mathrm{ng} . \mathrm{L}^{-1}$ for $\mathrm{EE} 2 \mathrm{in}$ raw sewage) and $0.1 \mathrm{ng} . \mathrm{L}^{-1}$ for secondary and tertiary effluents. Mean accuracies of all the analytes generally range from $90 \%$ to $103 \%$ in tertiary effluent, $80 \%$ to $123 \%$ in secondary effluent, and $91 \%$ to $113 \%$ in raw
sewage, with the exception of ethinylestradiol (between $40 \%$ and 55\%) (Table1). A sample sewage, with the exception of ethinylestradiol (between $40 \%$ and $55 \%$ ) (Table1). A sample
chromatograph is shown in Figure 1 . Note that accuracies are based on the raw sample before any sample preparation or filtration. The relative standard deviation (RSD) varied from $1 \%$ to $13 \%$ for all matrices studied, with the exception of ethinylestradiol in raw sewage (RSD between $14 \%$ and $48 \%$ ). These values indicate a satisfactory reproducibility and precision of the whole analytical procedure for E1 and E2 for each studied matrix but lower confidence for EE2 in the raw sewage. The poorer analytical sensitivity of EE2 in the raw sewage is believed to be due to the higher solids content in the raw sewage and greater adsorption of EE2 compared to E1 and E2 on the sludge particles, which are removed during filtration prior to SPE. In contrast, high accuracies of EE2 are obtained from secon are effluent, tertiary efflent and he sludge validain effluent, tertiary effluent and the sludge validation results, which also pass through the SPE clean-up procedure. Mean accuracies of each analyte from dewatered waste activated sludge were $75 \%$ for E1 1). The 2 , and $95 \%$ for EE2. The RSD vaies fable 1). These values indicate a satisfactory reproducibility and precision of the whole analytical procedure for the sludge matrix.

\section{Steroid estrogen concentration and behaviour within the Advanced STP}

The average concentrations of E1, E2 and EE2 in the raw sewage were 55, 22 and $<5.0$ ng.L respectively. The E1 and E2 figures are in good agreement with reported raw sewage concentrations in other studies $(20-22,24,27)$ and the extent of estrogen removal for each unit process in the advanced sewage treatment plant is summarised in Table 2. The sequential batch reactor (SBR) removed on average $85 \%$ of the incoming E1 and $96 \%$ of the E2, similar to reported percentages removed by activated sludge in other studies $(20-22,27,31)$. Studies indicate that E1 could be formed by the oxidation of E2 under aerobic conditions (31-33). In this work, there is no clear evidence of this reaction in the water samples analysed; however, when non-autoclaved dewatered waste activated sludge (WAS) from this plant is spiked with a mixture containing the same concentration of E1, E2, and EE2, analysis $40 \mathrm{~min}$ later gives almost double the amount of E1, similar to the spiked concentration for EE2, and very low concentrations of E2 (data not shown) indicating almost 100\% conversion of E2 to E1. The significantly lower proportion of E2 found in the mixed liquor suspended solids (MLSS; wastewater and activated sludge) (2\% of influent) compared to E1 (34\% of influent) (see mass balance in Figure 2) also suggests that E2 is being oxidized to E1 during the biological oxidation process. The mass balance around the SBR indicates that $25 \%$ of the E1+E2 total mass load accumulates in MLSS, whereas 9\% of E1, 1\% of the E2 and 6\% of the E1+E2 total mass load is removed from the activated sludge process in the form of WAS. This is similar to the $10 \%$ of the influent estrogenc activity found by Holbrook et al. (27) using an estradiol-equivalent screening assay (34) who foul (27) un some $30 \%$ of E2 being removed in the waste sludge. The dewatered sludge contains similar although slightly lower estrogen levels, possibly due to estrogen losses in the filtrate. The extensive concentration factor of solids in the sludge enables the detection of EE2 (0.42 ng. $\mathrm{g}^{-1}$ of solids) previously undetectable in the raw sewage. EE2 persistence has been documented by Vader et al (35) and Layton et al. (36) who found only $40 \%$ mineralization of ${ }^{14} \mathrm{C}-\mathrm{EE} 2$ to ${ }^{14} \mathrm{CO}_{2}$ over a $24 \mathrm{~h}$ period.

The biologically treated effluent is then stored in a holding tank before passing through the microfiltration plant. During microfiltration the concentrations of E1 and E2 were further reduced from 4.1 and $0.75 \mathrm{ng} . \mathrm{L}^{-1}$ to 1.2 and $0.1 \mathrm{ng} . \mathrm{L}^{-1}$, respectively. No E1 or E2 was detected after reverse osmosis and later chlorination. The high level of estrogen removal during microfiltration is most likely due to combination of adsorption onto the hollow-fiber membranes (37) and onto the dynamic membrane filter (38). Chang et al. (37) recently demonstrated almost $100 \%$ removal of radiolabelled E1 by adsorption on $0.2 \mu \mathrm{m}$ hydrophobic polypropylene hollow fibre membranes (the same as microfiltration adsorption on $0.2 \mu \mathrm{m}$ hydrophobic polypropylene hollow fibre membranes (the same as microfiltration membranes used at the advanced STP). Huang and Sedlak ( 12$)$ also detected the presence of E2 (1.36
ng. $\left.L^{-1}\right)$ and EE2 $\left(0.14 \mathrm{ng} \mathrm{L}^{-1}\right)$ after microfiltration and even trace levels of E2 $\left(0.24 \mathrm{ng} \mathrm{L}^{-1}\right)$ after reverse ng. $\left.\mathrm{L}^{-1}\right)$ and EE2 $\left(0.14 \mathrm{ng} . \mathrm{L}^{-1}\right)$ after microfiltration and even trace levels of E2 $\left(0.24 \mathrm{ng} . \mathrm{L}^{-1}\right)$ after reverse
osmosis. The transport mechanisms underpinning estrogen removal during nanofiltration and reverse osmosis membranes are discussed further in Khan et al (39) and Nghiem and Schäfer (40). 
Braga, O. ; Smythe, G.A. ; Schäfer, A.I. ; Feitz, A.J. (2005) Fate of steroid estrogens in Australian inland and coastal wastewater treatment plants,

\section{Estrogens in the enhanced primary STP}

The concentration of estrogens in the raw sewage of the enhanced primary STP is similar those found in the advanced STP, i.e. the average concentration are $58 \mathrm{ng} . \mathrm{L}^{-1}$ for E1, $14 \mathrm{ng} . \mathrm{L}^{-1}$ for E2 and $<5.0 \mathrm{ng} . \mathrm{L}^{-}$ ${ }^{1}$ for EE2 (Table 3). EE2 concentration for both plants is comparatively low, however, below the 8.8 ng. $\mathrm{L}^{-1}$ identified in Johnson et al. (41), $8.2 \mathrm{ng} . \mathrm{L}^{-1}$ in Andersen et al. (28) and $6 \mathrm{ng} . \mathrm{L}^{-1}$ in Ternes et al (20). The results are consistent with the lower levels reported by Baronti et al (21). The lower concentration of EE2 is primarily due to the low abundance expected in sewage. Prescriptions records in Australia (42) indicate that the total amount of EE2 dispensed in its various forms is approximately $9.77 \mathrm{~kg} . \mathrm{yr}^{-1}$ during 2000 (Table 4). The total proportion of women aged between 18-50 during 2000 was $46.9 \%$ (43) and of this approximately $26.7 \%$ used oral contraceptives (44). The equivalen annualized daily EE2 dose for women using oral contraceptives with EE2 is therefore $22.2 \mu \mathrm{g} \mathrm{p}^{-1} \mathrm{~d}^{-1}$. The majority of Australian women that use The majority levonorgestrel form Alaton $(42,45)$. Whe the expected annualized daily dose of $22.5 \mu \mathrm{g} \cdot \mathrm{p}^{-1} . \mathrm{d}^{-1}$. The coastal enhanced primary sewage treatment plan treats wastewater for some 1.7 million people, of which approximately 100,000 people would be women taking oral contraceptives based on the above statistics. Assuming that all EE2 is excreted and detectable in the raw sewage, and neglecting possible losses and non-active forms, the maximum concentration of EE2 expected would be $4.9 \mathrm{ng} . \mathrm{L}^{-1}$. Johnson and Williams (6) estimate that $40 \%$ of EE2 ingested, following deconjugation, will be available as free EE2 in the sewer which would lower the maximum (without considering losses in the system) to $2.0 \mathrm{ng} . \mathrm{L}^{-1}$. This is considerably less than detected in other studies and is a reflection of the proportion of women aged between 18-50 of the tota population and the degree that oral contraceptives are used.

Unlike the advanced STP where some $85-96 \%$ of estrogens are removed in the initial biological treatment stage, there is essentially no removal of the estrogens during treatment at the enhanced treatment stage, there is essentially no removal of the estrogens during treatment at the enhanced
primary STP. The ocean discharge concentration for E1 is $54 \mathrm{ng} . \mathrm{L}^{-1}$ and $14 \mathrm{ng} . \mathrm{L}^{-1}$ for E2, equating to primary STP. The ocean discharge concentration for E1 is $54 \mathrm{ng} . \mathrm{L}^{-1}$ and $14 \mathrm{ng} \cdot \mathrm{L}^{-1}$ for E2, equating to only $7 \%$ removal for E1 and $0 \%$ for E2 (Table 3). Similar poor estrogen removal rates during primary treatment has been observed by Andersen et al. (28), Ternes et al. (20), Holbrook et al. (27), Svenson et al. (24) and Desbrow et al. (2). Despite a 50\% reduction in influent non-filterable residue at the enhanced primary STP, from an average of 258 to $130 \mathrm{mg} . \mathrm{L}^{-1}$, and $60 \%$ reduction in oil and grease concentration, there is no corresponding drop in E1 or E2 concentration. The percentage removal results suggest that the compounds are not partitioning onto the nonpolar fat and lipid material in the raw sewage. This low removal is not surprising given the relatively low solids concentration in the raw wastewater (i.e. TSS $=258 \mathrm{mg} \cdot \mathrm{L}^{-1}$ ). For example, if considering estrone, the generalized expression for relating $\mathrm{K}_{\mathrm{oc}}$ and $\mathrm{K}_{\mathrm{ow}}$ values for nonpolar compounds (46) can be used to estimate the $\log \mathrm{K}_{\mathrm{oc}}\left(\log \mathrm{K}_{\mathrm{ow}}=\right.$ relating
3.4 :

$\log \mathrm{K}_{\mathrm{oc}}=\log \mathrm{K}_{\mathrm{ow}}-0.317$

$\log \mathrm{K}_{\mathrm{oc}}=3.4-0.317=3.1$

The $\log \mathrm{K}_{\mathrm{oc}}$ value is similar to that determined by Lee et al. (47) for estrone partitioning onto differen soils (i.e. $\log \mathrm{K}_{\mathrm{oc}}=3.1 \mathrm{cf}$. 3.2). It is then possible to estimate the weight fraction of reduced organic carbon $\left(\mathrm{f}_{\mathrm{oc}}\right)$ given that the volatile suspended solids of the raw wastewater is $85 \%$ and using the convention that organic carbon is approximately $50 \%$ of the natural organic matter (48), i.e.

$\mathrm{f}_{\mathrm{oc}} \sim 0.85 \times 0.5 \sim 0.43$
By only considering sorption due to partitioning onto the organic matter and neglecting any possible electrostatic effects or complexation adsorption reactions, the sorption constant, $\mathrm{K}_{\mathrm{d}}$ can be estimated by (48):

$\mathrm{K}_{\mathrm{d}}=\mathrm{K}_{\mathrm{oc}} \times \mathrm{f}_{\mathrm{oc}}=1258 \times 0.43=540$

The fraction of estrone in the water, $\mathrm{f}_{\mathrm{w}}$, can then be related to $\mathrm{K}_{\mathrm{d}}$ and the solids concentration in the wastewater, $\mathrm{r}_{\mathrm{sw}}$, using the following expression (48):

$\mathrm{f}_{\mathrm{w}}=\frac{1}{1+\mathrm{r}_{\mathrm{sw}} \cdot \mathrm{K}_{\mathrm{d}}}$

$$
\mathrm{f}_{\mathrm{w}}=\frac{1}{1+0.000258 \cdot 540}=\frac{1}{1+0.14}=0.88
$$

Hence, only $12 \%$ of the E1 - and using the same approach - 30\% of E2 would be expected to be associated with the organic fraction. Given that approximately 50\% of the suspended solids are removed, only a small fraction of E1 and E2 (6\% and 15\%) are likely to be removed via this mechanism, which is similar to the low observed removal rates, i.e. $7 \%$ for $0 \%$ for E1 and E2, respectively. There is likely to be little conversion of E2 to E1 under the anaerobic conditions encountered during primary clarification. In contrast, the $\mathrm{r}_{\mathrm{sw}}$ for the activated sludge processes in the ASTP plant is almost ten times greater and hence a much greater degree of initial sorption is expected.

The extent to which E1 and E2 are sorbed onto fine particles that are not removed at the treatment plant is not clear. Treated effluent samples were collected and centrifuged at high-speed $(10,000 \mathrm{rpm}, 2$ x $20 \mathrm{~min}, 10^{\circ} \mathrm{C}$ ) to separate solids from the aqueous layer and both layers were analysed for estrogens. Results clearly showed the presence of E2 and EE2 in the solid phase in each of the analysed samples. A precise quantification was not possible at such low concentrations using d4-E1 is used as internal standard; however, by comparing the estrogens concentration in water samples that were no centrifuged to the aqueous phase from centrifuged samples it was possible to estimate a percentage of estrogen attached to solid particles. EE2 was only identified in the solids fraction (i.e. 100\% adsorption), whereas the extent of adsorption for E1 in the effluent was $24 \%$ and $43 \%$ for $\mathrm{E} 2(\mathrm{n}=6)$.

We are obliged to be somewhat speculative with regards to the processes determining this high level of association with the solids fraction given that it cannot be accounted for by bulk partitioning onto organic matter. Lai et al. (J) observed increasing sorption onto river sediments with $0.3-3.3 \%$ organic carbon but also some $40 \%$ removal of estrogens sorbed to pure iron oxide, presumably through ion exchange between the surface hydroxyl group on the oxide and the polar phenolic steroids. Similar although lower, sorption was observed by Schäfer et al. (38) for E1 onto hematite and clays in the presence of natural organic matter. The influent to the enhanced primary STP, unlike the advanced STP, is pre-dosed with $\mathrm{FeCl}_{2}$ upstream in the sewerage system to control sulfide odours before reaching the plant. This results in the formation of fine black FeS particles that have been observed to leave in the treated effluent. The equivalent dose is $2 \mathrm{mg} \mathrm{Fe} . \mathrm{L}^{-1}$ wastewater and an additional $10 \mathrm{mg}$ $\mathrm{FeCl}_{3} \cdot \mathrm{L}^{-1}$ is added during the chemical assisted sedimentation (CAS) process. Iron is the dominan metal in the treated effluent (Table 5) and is presumably present as a mixture of surface hydrolyzed (4) the sluce During a . Fe content of the $\mathrm{Al}$ content $0.7 \mathrm{~g} .100 \mathrm{~g}^{-1}$ on a dry weight basis. It is proposed that estrogens may be sorbed onto fine
inorganic-organic aggregates leaving the effluent, enhanced by sorbed natural organic matter, and pass 
Braga, O. ; Smythe, G.A. ; Schäfer, A.I. ; Feitz, A.J. (2005) Fate of steroid estrogens in Australian inland and coastal wastewater treatment plants,

through the treatment system unaffected by the flocculation and sedimentation process. In addition, the $\mathrm{K}_{\mathrm{oc}}$ for sorption onto organic colloidal particles may be considerably greater than that determined from bulk partitioning $(50,51)$ as the nature of the organic constituents strongly affects the $\mathrm{K}_{\mathrm{oc}}(52)$. Recently Holbrook et al (53) have shown that the sorption coefficients for E2 and EE2 on organic colloids are higher than expected based on the octanol-water partition coefficient. Further, recent analyses of marine sediment samples adjacent and $7 \mathrm{~km}$ from the deep ocean outfall were found to contain all three estrogens at nanogram per gram concentrations (54). Studies monitoring total organic carbon (TOC) and particle size in the ocean sediments indicate that there is a slight increase in TOC and presence of finer particles at the $7 \mathrm{~km}$ sampling site compared to at the outfall (55). Substantially higher TOC and a greater presence of fine particles was found 3 to $5 \mathrm{~km}$ from the outfall, suggesting that highe concentrations of particles and hence estrogens may be located in this region.

A clear implication of this work is that enhanced primary treatment does not to remove estrogens and any large scale treatment using this technology may result in a considerable estrogen load to the surrounding marine environment. Their effect on sensitive environments, such as coral reefs, is surrouling particul con a propotion of the estogens higher ionic strength seawater and settle to the sea floor (54). The effect that estrogens have on marin invertebrates in the sediments and the wider marine ecosystem is unknown. Since enhanced primar STPs are considered one of the most suitable technologies for coping with the vast quantities of wastewater from mega cities such as Mexico City, Los Angeles, Hong Kong, Sao Paulo, Rio de Janeir and Istanbul $(56,57)$, it is important to determine whether the release of estrogens into the environment will affect the marine ecosystem. The high levels of dilution may prove sufficient for the prevention of endocrine effects in marine animals from deep ocean coastal outfalls but could prove problematic for discharges into large bays or harbours where flushing is limited (10). Under such conditions, microbia mediated degradation of estrogens may take several weeks (58). The presence of estrogens in anoxic marine sediments, where degradation is slower (58), presents a greater chance for estrogenic activity and accumulation in the environment. Further studies are needed to determine whether estrogen and present at nanogram per gram concentrations in the sediments affect marine invertebrates and whether
this poses a risk to the marine ecosystem.

\section{Acknowledgements}

Scholarship and financial support from BMSF and the UNSW Faculty of Engineering for Olga Braga is gratefully acknowledged, as is the assistance with the sampling programme from Paul Dixon, Andrew Horton and Hugh Chapman (Sydney Water Corporation). Comments provided by Fulbright Professorial Fellow David L. Sedlak are also greatly appreciated. Matthias Bonerz and Thomas Terne (ESWE Wiesbaden) are acknowledged for their support with initial studies funded by BMB\&F, Germany, and the authors would also like to thank Mr Ray Williams for the generous provision of mass spectrometer equipment. 
Braga, O. ; Smythe, G.A. ; Schäfer, A.I. ; Feitz, A.J. (2005) Fate of steroid estrogens in Australian inland and coastal wastewater treatment plants Environmental Science \& Technology, 39, 3351-3358. PLUS CORRECTION: (18): 7344-7344

\section{References}

1. Purdom, C.E.; Hardiman, P.A.; Bye, V.J.; Eno, N.C.; Tyler, C.; Sumpter, J.P. Estrogenic effects of effluents from sewage treatment works. Chem. Ecol. 1994, 6, 275-285.

2. Desbrow, C.; Routledge, E.J.; Brighty, G.C.; Sumpter, J.P.; Waldock, M. Identification of estrogenic chemicals in STW effluent: 1. Chemical fractionation and in vitro biological screening. Environ. Sci. Technol. 1998, 32, 1549-1557.

3. Routledge, E.J.; Sheahan, D.; Desbrow, C.; Brighty, G.C.; Waldock, M.; Sumpter, J.P. Identification of estrogenic chemicals in STW effluent: 2. In vivo responses in trout and roach. Environ. Health Perspect. 1998, 32, 1559-1565.

4. Johnson, A.C.; Sumpter, J.P. Removal of endocrine-disrupting chemicals in activated sludge treatment works. Environ. Sci. Technol. 2001, 35, 4697-4703.

5. Lai, K.M.; Johnson, K.L.; Scrimshaw, M.D.; Lester, J.N. Binding of waterbourne steroi estrogens to solid phases in river and estuarine systems. Environ. Sci. Technol. 2000, 34, 38903894.

6. Johnson, A.C.; Williams, R.J. A model to estimate influent and effluent concentrations of estradiol, estrone, and ethinylestradiol at sewage treatment works. Environ. Sci. Technol. 2004, 38, 3649-3658.

7. Kuch, H.M.; Ballschmitter, K. Determination of endocrine-disrupting phenolic compounds and estrogens in surface and drinking water by HRGC-(NCI)-MS in the picogram per liter range. Environ. Sci. Technol. 2001, 35, 3201-3206.

8. Snyder, S.A.; Villeneuve, D.L.; Synder, E.M.; Giesy. J.P. Identification and quantification of estrogen receptor agonists in wastewater effluents. Environ. Sci. Technol. 2001, 35, 3620-3625.

9. Alder, P.; Steger-Hartmann, T.; Kalbfus, W. Distribution of natural and synthetic estrogenic steroid hormones in water samples from Southern and Middle Germany. Acta Hydrochim. Hydrobiol. 2001, 29, 227-241.

10. Atkinson, S.; Atkinson, M.J.; Tarrant, A.M. Estrogens from sewage in coastal marine environments, Environ. Health Perspect. 2003, 111, 531-535.

11. Tashiro, Y.; Takemura, A.; Fujii, H.; Takahira K.; Nakanishi. Y. Livestock wastes as a source of estrogens and their effects on wildlife of Manko tidal flat, Okinawa. Mar. Pollut. Bull. 2003, 47 , 143-147.

12. Peck, M; Gibson, R.W.; Kortenkamp, A.; Hill, E.M. Sediments are major sinks of steroidal estrogens in two United Kingdom rivers. Environ. Toxicol. Chem. 2004, 23, 945-952.

13. Williams, R.J.; Johnson, A.C.; Smith, J.J.L.; Kanda, R. Steroid estrogens profiles along river stretches arising from sewage treatment works discharges. Environ. Sci. Technol. 2003, 37, 1744 1750.
14. de Alda, M.J.L.; Gil, A.; Paz, E.; Barcelo, D. Occurrence and analysis of estrogens and progestogens in river sediments by liquid chromatography-electrospray-mass spectrometry, Analyst 2002, 127, 1299-1304.

15. Holthaus, K.I.E.; Johnson, A.C.; Jurgens, M.D.; Williams, R.J.; Smith, J.J.L.; Carter, J.E. The potential for estradiol and ethinylestradiol to sorb to suspended and bed sediments in some English rivers. Environ. Toxicol. Chem. 2002, 21, 2526-2535.

16. Mibu, K.; Wada, J.; Okayasu, Y.; Tsumori, J.; Komori, K.; Tanaka, H.; Li, J.H.; Sasaki, M.; Sato, C. Distribution of estrogen, nonylphenol and its derivatives in the sediments of a shallow lake. Water Sci. Technol. 2004, 50, 173-179.

17. Thomas, K.V.; Balaam, J.; Hurst, M.; Nedyalkova, Z.; Mekenyan, O. Potency and characterization of estrogen-receptor agonists in united kingdom estuarine sediments, Environ. Toxicol. Chem. 2004, 23, 471-479.

18. Thomas, K.V.; Hurst, M.R.; Matthiessen, P.; Waldock, M.J. Characterization of estrogenic compounds in water samples collected from United Kingdom estuaries, Environ. Toxicol. Chem. 2001, 20, 2165-2170.

19. Holthaus, K.IE. Johnson, A.C.; Jürgens, M.D.; Williams, R.J.; Smith, J.J.L. Carter, J.E. The potential for estradiol and ethintlestradiol to srob to suspended and bed sediments in some English rivers. Environ. Toxicol. Chem. 2002, 21, 2526-2535.

20. Ternes, T.A.; Stumpf, M.; Mueller, J.; Haberer, K.; Wilken, R.-D.; Sevos, M. Behaviour and occurrence of estrogens in municipal sewage treatment plants - I. Investigations in Germany, Canada and Brazil. Sci. Total Environ. 1999, 225, 81-90.

21. Baronti, C.; Curini, R.; D’Ascenzo, G.; Di Corcia, A.; Gentili, A.; Samperi, R. Monitoring natura and synthetic estrogens at activated sludge sewage treatment plants and in a receiving river water Environ. Sci. Technol. 2000, 34, 5059-5066.

22. Nasu, M.; Goto, M.; Oshima, Y.; Tanaka, H. Study on endocrine disrupting chemicals in wastewater treatment plants. Water Sci. Technol. 2001, 43, 101-108.

23. Huang, C.H.; Sedlak, D.L. Analysis of estrogenic hormones in municipal wastewater effluent and surface water using enzyme-linked immunosorbent assay and gas chromatography/tandem mass spectrometry. Environ. Toxicol. Chem. 2001, 20, 133-139.

24. Svenson, A.; Allard, A.S.; Ek, M. Removal of estrogenicity in Swedish municipal sewage treatment plants. Water Res. 2003, 37, 4433-4443.

25. Körner, W.; Spengler, P.; Bolz, U.; Metzger, J.W. Substances with estrogenic activity in effluents of sewage treatment plants in southwestern Germany. 2. Biological analysis Environ. Toxicol. Chem. 2001, 20, 2142-2151.

26. Murk, A.J.; Legler, J.; van Lipzig, M.M.H.; Meerman, J.H.N.; Belfroid, A.C.; Spenkelink, A. van der Burg, R.; Rijs, G.B.J.; Vethaak, D. Detection of estrogenic potency in wastewater and surface water with three in vitro bioassays. Environ. Toxicol. Chem. 2002, 21, 16-23. 
27. Holbrook, R.D.; Novak, J.T.; Grizzard, T.J.; Love, N.G. Estrogen receptor agonist fate during wastewater and biosolids treatment processes: A mass balance approach. Environ. Sci. Technol. 2002, 36, 4533-4539.

28. Andersen, H.; Siegrist, H.; Halling-Sørensen, B.; Ternes, T.A. Fate of estrogens in a municipal sewage treatment plant. Environ. Sci. Technol. 2003, 37, 4021-4026.

29. Joss, A.; Andersen, H.; Ternes, T.; Richle, P.R.; Siegrist, H. Removal of estrogens in municipal wastewater treatment under aerobic and anaerobic conditions: Consequences for plant optimization, Environ. Sci. Technol. 2004, 38, 3047-3055.

30. Nakamura, S.; Sian, T.H.; Daishima, S. Determination of estrogens in river water by gas chromatography-negative-ion chemical-ionization mass spectrometry. J. Chromatography A 2001, 919, 275-282.

31. Onda, K.; Nakamura, Y.; Takatoh, C.; Miya, A.; Katsu, Y. The behavior of estrogenic substances in the biological treatment process of sewage. Water Sci. Technol. 2003, 47, 109-116.

32. Ternes, T.A.; Kreckel, P.; Mueller, J. Behavior and occurrence of estrogens in municipal sewage treatment plants - II. Aerobic batch experiments with activated sludge. Sci. Total Environ. 1999, 225, 91-99.

33. Lee, H.B.; Liu, D. Degradation of $17 \beta$-estradiol and its metabolites by sewage bacteria, Water Air Soil Pollut. 2002, 134, 353-368.

34. Takigami, H.; Taniguchi, N.; Matsuda, T.; Yamada, M.; Shimizu, Y.; Matsui, S. The fate and behaviour of human estrogens in a night soil treatment process. Water Sci. Technol. 2000, 42, 45 51 .

35. Vader, J.S.; van Ginkel, C.G.; Sperling, F.M.G.M.; de Jong, J.; de Boer, W.; de Graaf, J.S.; van der Most, M.; Stokman, P.G.W. Degradation of ethinyl estradiol by nitrifying activated sludge, Chemosphere, 2000, 41, 1239-1243.

36. Layton, A.C.; Gregory, B.W.; Seward, J.R.; Schultz, T.W.; Sayler, G.S. Mineralization of steroidal hormones by biosolids in wastewater treatment systems in Tennessee U.S.A. Environ. Sci. Technol. 2000, 34, 3925-3931.

37. Chang, S.; Waite, T.D.; Schäfer, A.I.; Fane, A.G. Adsorption of the endocrine-active compound estrone on microfiltration hollow fiber membranes. Environ. Sci. Technol. 2003, 37, 3158-3163.

38. Schäfer, A.I.; Mastrup, M.; Jensen, R.L. Particle interactions and removal of trace contaminants from water and wastewaters. Desalination 2002, 147, 243-250.

39. Khan, S.J.; Wintgens, Y; Sherman, P.; Zaricky, J; Schäfer, A.I. Removal of hormones and pharmaceuticals in the advanced water recycling demonstration plant in Queensland. Water Sci. Technol. 2004, 50, 15-22.

40. Ngheim, L.D.; Schäfer, A.I. Adsorption and transport of trace contaminant estrone in NF/RO membranes. Environ. Eng. Sci. 2002, 19, 441-451.
41. Johnson, A.C.; Belfroid, A.; di Corcia, A. Estimating steroid inputs into activated sludge treatment works and observations on their removal from the effluent. Sci. Total Environ. 2000, treatment wo $163-173$

42. Commonwealth Department of Health and Ageing, Australian Statistics on Medicines: 1999. 2000, AusInfo: Canberra, 2003.

43. Australian Bureau of Statistics, Population by Age and Sex, Cat. No. 3201.0, ABS: Canberra, 2003

44. Australian Bureau of Statistics, Australian Social Trends 1998: Family - Family Formation: Family planning, Cat. No. 4102.0, ABS: Canberra, 1998.

45. Riddoch, G. The combined oral contraceptive pill. Aust. Family Physician 2000, 29, 1039-1044.

46. Means, J.C.; Wood, S.G.; Hassett, J.J.; Banwart, W.L. Sorption of amino- and carboxysubstituted polynuclear aromatic hydrocarbons by sediments and soils. Environ. Sci. Technol. 1982, 16, 93-98.

47. Lee, L.S.; Strock, T.J.; Sarmah, A.K.; Rao, P.S. Sorption and dissipation of testosterone, estrogens, and their primary transformation products in soils and sediment. Environ. Sci. Technol. 2003, 37, 4098-4105.

48. Schwarzenbach, R.P.; Gschwend, P.M.; Imboden, D.M. Environmental Organic Chemistry, 2nd ed.; John Wiley \& Sons: Hoboken, NJ, 2003.

49. Butler, E.C.; Hayes, K.F. Effects of solution composition and $\mathrm{pH}$ on the reductive dechlorination of hexachloroethane by iron sulfide. Environ. Sci. Technol. 1998, 32, 1276-1284.

50. Sprague, L.A.; Herman, J.S.; Hornberger, G.M.; Mills, A.L. Atrazine adsorption and colloidfacilitated transport through the unsaturated zone. J. Environ. Qual. 2000, 29, 1632-1641.

51. Irace-Guigand, S.; Aaron, J.J. The role of organic colloids in herbicide transfer to rivers: a quantitative study of triazine and phenylurea interactions with colloids. Anal. Bioanal. Chem 2003, 376, 431-435.

52. Gustafsson, O.; Nilsson, N.; Bucheli, T.D. Dynamic colloid-water partitioning of pyrene through a coastal Baltic spring bloom. Environ. Sci. Technol. 2001, 35, 4001-4006.

53. Holbrook, R.D.; Love, N.G.; Novak, J.T. Sorption of 17-beta-estradiol and 17 alphaethinylestradiol by colloidal organic carbon derived from biological wastewater treatmen systems. Environ. Sci. Technol. 2004, 38, 3322-3329.

54. Braga, O.; Feitz, A.J.; Smythe, G.; Schafer, A.I. Steroid estrogens in ocean sediments, Chemosphere 2005 (submitted)

55. Australian Water Technologies, Sydney Water, NSW Environment Protection Authority, 2000. Offshore Sediment Program 2000: Report - Final. AWT, Sydney. 
Braga, O. ; Smythe, G.A. ; Schäfer, A.I. ; Feitz, A.J. (2005) Fate of steroid estrogens in Australian inland and coastal wastewater treatment plants, Environmental Science \& Technology, 39, 3351-3358. PLUS CORRECTION: (18): 7344-7344

DOI: $10.1021 / \mathrm{es} 0501767$

56. Harleman, D.R.F.; Murcott, S. The role of physical-chemical wastewater treatment in the megacities of the developing world. Water Sci. Technol. 1999, 40, 75-80.

Table 1

57. Eroglu, V.; Sarlkaya, H.Z.; Aydin, E. Planning of wastewater treatment and disposal systems of Istanbul metropolitan area. Water Sci. Technol. 2001, 44, 31-38.

58. Ying, G.G.; Kookana, R.S. Degradation of five selected endocrine disrupting chemicals in seawater and marine sediments. Environ. Sci. Technol. 2003, 37, 1256-1260.

59. Sydney Water Corporation, Environmental Indicators Compliance Report 2002 http://www.sydneywater.com.au/html/environment/eicr/eicrpdfs.html, Feb 2004.

\section{Table captions}

Table 1. Precision and accuracy of the ECNI GC-MS assays for E1, E2 and EE2 in each studied water matrix and in dewatered sludge

Table 2. Concentration of estrogens in the advanced STP

Table 3. Concentration of estrogen at the enhanced primary STP

Table 4. Ethinyloestradiol use in Australia during 2000 (42)

Table 5. Major ions in EP STP treated effluent (59)

\section{Figure captions}

Figure 1. Sample ECNI GC-MS chromatogram for analysis of E1, E2 and EE2 in raw sewage spiked with $10 \mathrm{ng} \cdot \mathrm{L}^{-1}$. The $[\mathrm{M}]$ ion and [M-TMS $]$ ions were monitored for all compounds. The traces show the monitored ions $271,272,273,269,343,367 \mathrm{~m} / \mathrm{z}$ for d4-E1 (internal standard), E1, E2, and EE2 respectively.

Figure 2. Mass balance for E1, E2 and E1+E2 for the advanced STP sequential batch reactor (MLSS = Mixed liquor suspended solids)

\begin{tabular}{|c|c|c|c|c|c|c|}
\hline $\begin{array}{c}\text { Tertiary } \\
\text { Effluent } \\
\text { (ng/L) }\end{array}$ & E1 & $\begin{array}{c}\text { Accuracy } \\
(\%)\end{array}$ & E2 & $\begin{array}{c}\text { Accuracy } \\
(\%)\end{array}$ & EE2 & $\begin{array}{c}\text { Accuracy } \\
(\%)\end{array}$ \\
\hline 1 & & & & & & \\
\hline $\begin{array}{c}\text { Mean } \\
\text { \%RSD } \\
10\end{array}$ & $\begin{array}{c}0.92 \\
5.4\end{array}$ & 92 & $\begin{array}{c}0.90 \\
2.8\end{array}$ & 90 & $\begin{array}{c}0.99 \\
3.7\end{array}$ & 99 \\
\hline Mean & 10.2 & 102 & 10.3 & 102 & 10.3 & 103 \\
\hline $\begin{array}{c}\% \text { RSD } \\
100\end{array}$ & 4.3 & & 1.7 & & 3.7 & \\
\hline $\begin{array}{l}\text { Mean } \\
\% \text { RSD }\end{array}$ & $\begin{array}{l}104 \\
1.2\end{array}$ & 103 & $\begin{array}{l}102 \\
1.5\end{array}$ & 102 & 103 & 103 \\
\hline $\begin{array}{c}\text { Secondary } \\
\text { Effluent } \\
\text { (ng/L) }\end{array}$ & E1 & $\begin{array}{c}\text { Accuracy } \\
(\%)\end{array}$ & E2 & $\begin{array}{c}\text { Accuracy } \\
(\%)\end{array}$ & EE2 & $\begin{array}{c}\text { Accuracy } \\
(\%)\end{array}$ \\
\hline 10 & & & & & & \\
\hline Mean & 8.4 & 84 & 9.5 & 95 & 9.1 & 91 \\
\hline $\begin{array}{c}\text { \%RSD } \\
50\end{array}$ & 2.5 & & 5.5 & & 3.9 & \\
\hline Mean & 47.7 & 95 & 50.1 & 100 & 39.9 & 80 \\
\hline$\%$ RSD & 2.0 & & 1.3 & & 0.8 & \\
\hline Mean & 101 & 101 & 123.2 & 123 & 99.6 & 100 \\
\hline$\%$ RSD & 3.7 & & 2.7 & & 2.4 & 100 \\
\hline $\begin{array}{c}\text { Raw } \\
\text { Sewage } \\
\text { (ng/L) }\end{array}$ & E1 & $\begin{array}{c}\text { Accuracy } \\
(\%)\end{array}$ & E2 & $\begin{array}{c}\text { Accuracy } \\
(\%)\end{array}$ & EE2 & $\begin{array}{c}\text { Accuracy } \\
(\%)\end{array}$ \\
\hline $\begin{array}{c}10 \\
\text { Mean }\end{array}$ & 11.3 & 113 & 94 & 94 & 53 & 55 \\
\hline $\begin{array}{c}\text { \%RSD } \\
50\end{array}$ & 5.7 & & $\begin{array}{l}3.4 \\
3.9\end{array}$ & & $\begin{array}{l}0.0 \\
13.6\end{array}$ & \\
\hline & 53.8 & 108 & 53.5 & 107 & 24.0 & 48 \\
\hline $\begin{array}{c}\% \text { RSD } \\
100\end{array}$ & 2.8 & & 3.2 & & 10.0 & \\
\hline $\begin{array}{l}\text { Mean } \\
\text { \%RSD }\end{array}$ & 96.5 & 96 & 91.0 & 91 & 40.2 & 40 \\
\hline $\begin{array}{l}\text { Dewatered } \\
\text { Sludge } \\
\text { (pg/ul) }\end{array}$ & E1 & $\begin{array}{c}\text { Accuracy } \\
(\%)\end{array}$ & $\begin{array}{l}9.4 \\
\text { E2 }\end{array}$ & $\begin{array}{c}\text { Accuracy } \\
(\%)\end{array}$ & $\begin{array}{l}\text { 4.6 } \\
\text { EE2 }\end{array}$ & $\begin{array}{c}\text { Accuracy } \\
(\%)\end{array}$ \\
\hline 100 & & & & & & \\
\hline Mean & 74.6 & 75 & 87.4 & 87 & 94.5 & 95 \\
\hline$\%$ RSD & 4.9 & & 18.9 & & 7.6 & \\
\hline
\end{tabular}

${ }^{*} \mathrm{RSD}$ is relative standard deviation 
Braga, O. ; Smythe, G.A. ; Schäfer, A.I. ; Feitz, A.J. (2005) Fate of steroid estrogens in Australian inland and coastal wastewater treatment plants, Environmental Science \& Technology, 39, 3351-3358. PLUS CORRECTION: (18): 7344-7344

DOI: $10.1021 / \mathrm{es} 0501767$

\section{Table 2}

Table 3

\begin{tabular}{|c|c|c|c|c|c|c|c|}
\hline \multirow[t]{2}{*}{ Water samples } & \multirow[b]{2}{*}{$\mathrm{n}$} & \multicolumn{2}{|c|}{$\begin{array}{c}\mathrm{E1} \\
(\mathrm{ng} / \mathrm{L})\end{array}$} & \multicolumn{2}{|c|}{$\begin{array}{c}\text { E2 } \\
\text { (ng/L) }\end{array}$} & \multicolumn{2}{|c|}{$\begin{array}{c}\text { EE2 } \\
(n g / L)\end{array}$} \\
\hline & & Average & Std dev. & Average & Std dev. & Average & Std dev. \\
\hline Raw sewage & 16 & 54.8 & 14.3 & 22.0 & 15.9 & $<5.0$ & \\
\hline SBR Effluent & 15 & 8.1 & 4.2 & 0.95 & 0.55 & $<0.1$ & \\
\hline$\%$ removal & & 85 & & 96 & & & \\
\hline CMF influent & 10 & 4.1 & 3.6 & 0.75 & 0.99 & $<0.1$ & \\
\hline CMF effluent & 16 & 1.2 & 2.6 & 0.10 & 0.24 & $<0.1$ & \\
\hline \% removal & & 70 & & 87 & & & \\
\hline RO effluent & 9 & $<0.1$ & & $<0.1$ & & $<0.1$ & \\
\hline Chlorination & 10 & $<0.1$ & & $<0.1$ & & $<0.1$ & \\
\hline$\%$ removal & & - & & - & & - & \\
\hline \multirow[t]{2}{*}{ Sludge samples } & & \multicolumn{2}{|c|}{$\begin{array}{c}\mathrm{E1} \\
(\mathrm{ng} / \mathrm{g})\end{array}$} & \multicolumn{2}{|c|}{$\begin{array}{c}\mathrm{E} 2 \\
(\mathrm{ng} / \mathrm{g})\end{array}$} & \multicolumn{2}{|c|}{$\begin{array}{c}\text { EE2 } \\
(\mathrm{ng} / \mathrm{g})\end{array}$} \\
\hline & $\mathrm{n}$ & Average & Std dev. & Average & Std dev. & Average & Std dev. \\
\hline Activated sludge & 4 & 11.8 & 4.7 & 0.31 & 8.11 & 0.42 & 0.32 \\
\hline Dewatered sludge & 4 & 14.3 & 3.8 & 0.57 & 2.87 & 0.61 & 0.67 \\
\hline
\end{tabular}

\begin{tabular}{|cccccccc|}
\hline Sample & \multicolumn{2}{c}{$\mathrm{E} 1$} & \multicolumn{2}{c}{$\mathrm{E} 2$} & \multicolumn{2}{c|}{ EE2 } \\
& \multicolumn{2}{c}{$\mathrm{ng} / \mathrm{L}$} & \multicolumn{2}{c|}{$\mathrm{ng} / \mathrm{L}$} \\
& $\mathrm{n}$ & Average $^{2}$ & Std dev. & Average & Std dev. & Average & Std dev. \\
\hline Raw sewage & 19 & 58.0 & 15.0 & 14.0 & 11.0 & $<5.0$ & - \\
Effluent & 19 & 54.0 & 13.0 & 14.0 & 10 & $<5.0$ & - \\
\% removal & & 45 & & 61 & & & \\
\hline $\begin{array}{c}\text { Centrifuged } \\
\text { effluent }\end{array}$ & 6 & 41.0 & 18.0 & 8.0 & 5.0 & $<1.0$ & \\
\hline
\end{tabular}


Braga, O. ; Smythe, G.A. ; Schäfer, A.I. ; Feitz, A.J. (2005) Fate of steroid estrogens in Australian inland and coastal wastewater treatment plants,

Environmental Scionce \& T Thnology 39, 3351-3358. PLUS CORRECTION: (18): 7344-7344

DOI: $10.1021 / \mathrm{es} 0501767$

Table 4

Table 5

\begin{tabular}{|c|c|c|c|c|c|c|c|}
\hline & & Code & $\begin{array}{l}\text { Number } \\
\text { EE2 } \\
\text { tablets/ } \\
\text { pkg }\end{array}$ & $\begin{array}{l}r \\
\text { Quantity } \\
\text { of EE2 } \\
\text { tablet }\end{array}$ & $\begin{array}{l}\text { Number } \\
\text { scripts }\end{array}$ & No. pkg per script & $\begin{array}{l}\text { total } \\
\text { tEE2 }\end{array}$ \\
\hline & & & & ug & & & $\mathrm{kg}$ \\
\hline \multirow[t]{16}{*}{ Fixed combinations } & \multirow{3}{*}{$\begin{array}{l}\text { Desogestrel with ethinyloestradiol } \\
\text { Ethinyloestradiol with gestodene }\end{array}$} & 14249 & 28 & 30 & 123283 & 4 & 0.41 \\
\hline & & 15082 & & 30 & 35320 & 2 & 0.04 \\
\hline & & 15084 & & 30 & 36066 & 2 & 0.05 \\
\hline & \multirow[t]{9}{*}{ Levonoergestrel with ethinyloestradiol } & 1393 & 21 & 30 & 35308 & 4 & 0.09 \\
\hline & & 1394 & 21 & 30 & 1215470 & 4 & 3.06 \\
\hline & & 1455 & 21 & 50 & 11275 & 4 & 0.05 \\
\hline & & 1456 & 21 & 50 & 125346 & 4 & 0.53 \\
\hline & & 3186 & 21 & 50 & 15945 & 4 & 0.07 \\
\hline & & 3188 & 21 & 50 & 32621 & 4 & 0.14 \\
\hline & & 16212 & 28 & 50 & 77411 & 4 & 0.43 \\
\hline & & 16217 & 28 & 20 & 156242 & 4 & 0.35 \\
\hline & & 16970 & 21 & 20 & 2454 & 4 & 0.00 \\
\hline & \multirow[t]{4}{*}{ Norethisterone with ethinyloestradiol } & 2772 & 21 & 35 & 8885 & 4 & 0.03 \\
\hline & & 2773 & 21 & 35 & 4959 & 4 & 0.01 \\
\hline & & 2774 & 21 & 35 & 186511 & 4 & 0.55 \\
\hline & & 2775 & 21 & 35 & 91006 & 4 & 0.27 \\
\hline \multirow[t]{16}{*}{ Seq. preparations } & \multirow[t]{6}{*}{ Ethinyloestradiol with gestodene } & 15087 & & 30 & 9069 & 2 & 0.00 \\
\hline & & & 5 & 40 & 9069 & 2 & 0.00 \\
\hline & & & 10 & 30 & 9069 & 2 & 0.01 \\
\hline & & 15088 & & 30 & 5305 & 2 & 0.00 \\
\hline & & & 5 & 40 & 5305 & 2 & 0.00 \\
\hline & & & 10 & 30 & 5305 & 2 & 0.00 \\
\hline & \multirow[t]{8}{*}{ Levonoergestrel with ethinyloestradiol } & 1391 & 6 & 30 & 19348 & 4 & 0.01 \\
\hline & & & 5 & 40 & 19348 & 4 & 0.02 \\
\hline & & & 10 & 30 & 19348 & 4 & 0.02 \\
\hline & & 1392 & 6 & 30 & 1236543 & 34 & 0.89 \\
\hline & & & 5 & 40 & 1236543 & 34 & 0.99 \\
\hline & & & 10 & 30 & 1236543 & 34 & 1.48 \\
\hline & & 1458 & 11 & 50 & 41115 & 4 & 0.09 \\
\hline & & & 10 & 50 & 41115 & 4 & 0.08 \\
\hline & Norethisterone with ethinyloestradiol & 2776 & 21 & 35 & 27231 & 4 & 0.08 \\
\hline & Total & & & & & & 9.77 \\
\hline
\end{tabular}

\begin{tabular}{|ll|}
\hline Analyte & $\begin{array}{l}\text { Average concentration } \\
(\mathrm{mg} / \mathrm{L})\end{array}$ \\
\hline Al & 0.76 \\
Ammonia & 26.6 \\
$\mathrm{Cl}$ & 194 \\
Fe & 5.6 \\
Oil and grease & 26 \\
Phosphate & 6.6 \\
Sulfate & 57 \\
Total suspended solids & 130 \\
Total N & 39.1 \\
Zn & 0.13 \\
\hline
\end{tabular}


Braga, O. ; Smythe, G.A. ; Schäfer, A.I. ; Feitz, A.J. (2005) Fate of steroid estrogens in Australian inland and coastal wastewater treatment plants, Environmental Science \& Technology, 39, 3351-3358. PLUS CORRECTION: (18): 7344-7344

DOI: $10.1021 /$ es0501767

Figure 1

1000

800

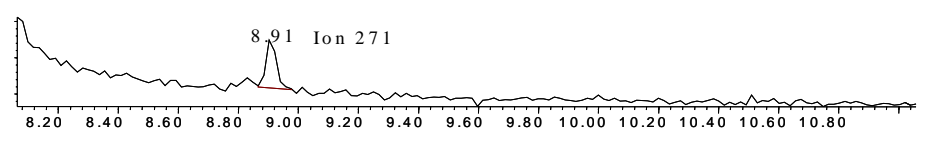

1000
800
600

$$
8.91 \quad \text { Ion } 272
$$

1000

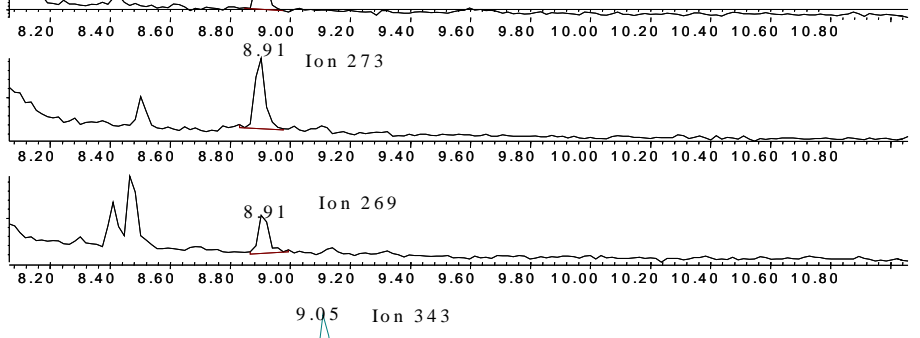

6000
4000
200

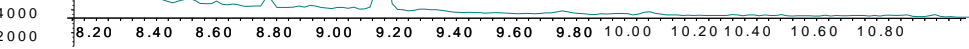

30000
20000

\section{lon 367}

$\begin{array}{llllllllllllllllllllllll}8.20 & 8.40 & 8.60 & 8.80 & 9.00 & 9.20 & 9.40 & 9.60 & 9.80 & 10.00 & 10.20 & 10.40 & 10.60 & 10.80\end{array}$

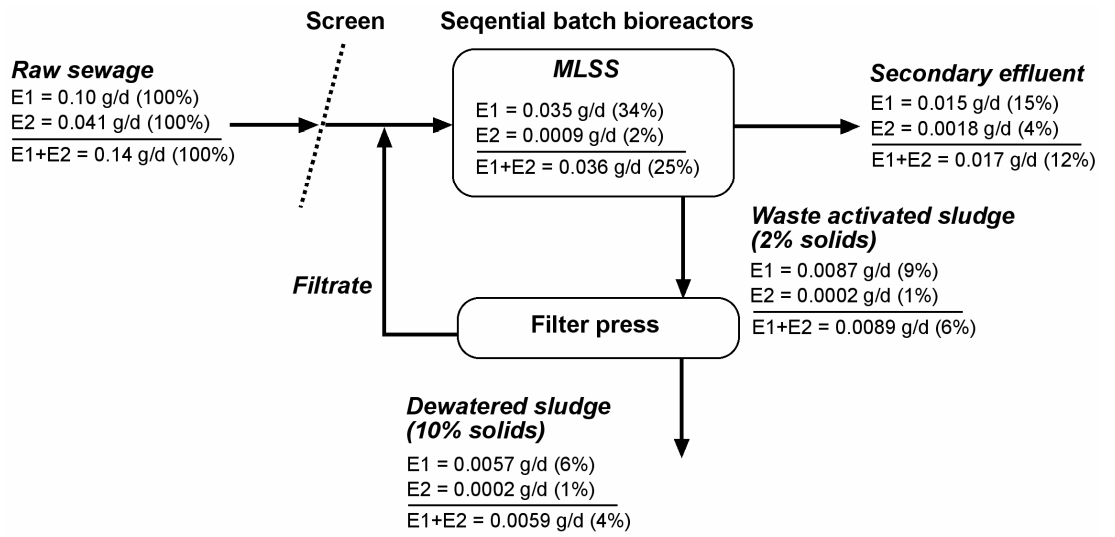

